\title{
Benzyl butyl phthalate induces migration, invasion, and angiogenesis of Huh7 hepatocellular carcinoma cells through nongenomic AhR/G-protein signaling
}

Cheng-Fang Tsai ${ }^{1}$, Tsung-Hua Hsieh ${ }^{1}$, Jau-Nan Lee ${ }^{2}$, Chia-Yi Hsu' ${ }^{1}$ Yu-Chih Wang ${ }^{2}$, Feng-Jie Lai ${ }^{3}$, Kung-Kai Kuo ${ }^{4}$, Hua-Lin Wu ${ }^{5,6,7}$, Eing-Mei Tsai ${ }^{1,2,8^{*}+}$ and Po-Lin Kuo ${ }^{*^{*}+}$

\begin{abstract}
Background: The widespread use of phthalates as plasticizers has raised public health concerns regarding their adverse effects, including an association with cancer. Although animal investigations have suggested an association between phthalate exposure and hepatocellular carcinoma, the mechanisms are unknown.

Methods: The hepatocellular carcinoma cell line Huh7 was treated with benzyl butyl phthalate (BBP), and then analyzed by total internal reflection fluorescence microscopy, confocal microscopy and double immunogold transmission electron microscopy. Following BBP treatment, mRNA levels were measured by RT-PCR, protein levels were measured using western blot, and vascular endothelial growth factor levels were measured by an enzyme-linked immunosorbent assay. Cell migration and invasion assays were evaluated by transwell, and angiogenesis were performed by a tube formation assay. Nude mice were used to investigate metastasis and angiogenesis in vivo.

Results: BBP affected hepatocellular carcinoma progression through the aryl hydrocarbon receptor (AhR) and that benzyl butyl phthalate (BBP) stimulated AhR at the cell surface, which then interacted with $G$ proteins and triggered a downstream signaling cascade. BBP activated AhR through a nongenomic action involving G-protein signaling rather than the classical genomic AhR action. BBP treatment promoted cell migration and invasion in vitro and metastasis in vivo via the $A h R / G_{\beta} / P I 3 K / A k t / N F-k B$ pathway. In addition, BBP induced both in vitro and in vivo angiogenesis through the AhR/ERKNEGF pathway.
\end{abstract}

Conclusions: These findings suggest a novel nongenomic AhR mechanism involving G-protein signaling induced by phthalates, which contributes to tumor progression of hepatocellular carcinoma.

Keywords: Phthalate, Aryl hydrocarbon receptor, Angiogenesis, Migration, Hepatocellular carcinoma

\section{Background}

Globally, hepatocellular carcinoma is the sixth most common cancer and the third most common cause of cancer-related deaths [1]. Risk factors for hepatocellular carcinoma include infection with hepatitis B or C viruses, alcohol consumption, smoking, and environmental factors

\footnotetext{
* Correspondence: tsaieing@yahoo.com; kuopolin@seed.net.tw

${ }^{\dagger}$ Equal contributors

'Graduate Institute of Medicine, College of Medicine, Kaohsiung Medical University, Kaohsiung City 807, Taiwan

${ }^{9}$ Institute of Clinical Medicine, College of Medicine, Kaohsiung Medical University, No. 100, Zihyou 1st Rd., Sanmin District, Kaohsiung, Taiwan Full list of author information is available at the end of the article
}

[2]. Oral administration of phthalates to rats results in liver enlargement and cause increased malondialdehyde levels in the liver, indicating that phthalates cause oxidative damage of the liver [3]. Bis(2-ethylhexyl) phthalate (DEHP) acts as a promoter of hepatocellular tumors initiated by $N$-nitrosodiethylamine [4]. Moreover, lifetime DEHP treatment induces testis and liver cancer in rats [5]. Based on proteomic analysis, the proteins secreted by HepG2 cells that have been treated with benzyl butyl phthalate (BBP) are associated with DNA damage, tumor progression, apoptosis, energy metabolism, and cell structure and motility [6]. The observed roles of BBP in DNA damage

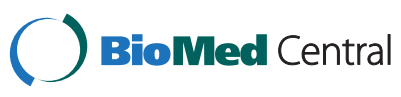

(c) 2014 Tsai et al.; licensee BioMed Central Ltd. This is an Open Access article distributed under the terms of the Creative Commons Attribution License (http://creativecommons.org/licenses/by/2.0), which permits unrestricted use, distribution, and reproduction in any medium, provided the original work is properly credited. The Creative Commons Public Domain Dedication waiver (http://creativecommons.org/publicdomain/zero/1.0/) applies to the data made available in this article, unless otherwise stated. 
and methylation, as well as cell migration, invasion, and proliferation suggest the involvement of BBP in tumor development and progression. These findings support carcinogenesis induced by phthalates, but the mechanism remains largely unknown.

Previous studies have shown that phthalates affect the activation of the aryl hydrocarbon receptor (AhR) $[7,8]$. Moreover, phthalates suppressed type I interferon expression in human plasmacytoid dendritic cells via AhR [9]. Our previous study showed that BBP induces necrosis in human granulosa cells via AhR activation followed by downstream CYP1B1 induction [10]. We also showed that phthalates induce proliferation and invasiveness of breast cancer through the AhR/HDAC6/c-Myc signaling pathway [11]. These results suggest that AhR is an important receptor that mediates multiple biological effects of phthalates.

The ligand-activated transcriptional factor AhR regulates the enzymatic functions needed for xenobiotic metabolism. Previous reports revealed two pathways that mediate AhR effects including genomic and non-genomic pathways. The classical genomic function involves AhR nuclear translocation and binding to xenobiotic responsive elements located in the promoters of target genes, CYP1A1 and CYP1B1 [12]. In addition to the classical genomic AhR function, AhR can regulate gene expression through a nongenomic mechanism. The Study of nongenomic signaling is important in the field of toxicology. It is difficult to identify dioxin response element (DRE)-based target genes and many reports suggest that the toxic effect of $2,3,7$, 8 -tetrachlorodibenzo-p-dioxin (TCDD) is more compatible with the nongenomic signaling of AhR, rather than the genomic action [13]. Moreover, our previous study reported a phthalate mediated AhR/HDAC6/c-Myc pathway that demonstrated a nongenomic effect of AhR [10]. Several studies have reported that TCDD induces inflammatory responses through a nongenomic AhR function [14-17], although this nongenomic AhR function remains poorly understood.

Here, we found that BBP promotes angiogenesis, migration and invasion in vitro as well as angiogenesis and metastasis in vivo of hepatocellular carcinoma. Because G-protein signaling is involved in the regulation of AhR stability [18], we further investigated the AhR function and its possible relationship to G-protein signaling in hepatocellular carcinoma.

Additionally, we revealed that the mechanism through which phthalates activate the nongenomic AhR pathway is associated with G-protein signaling.

\section{Methods}

\section{Chemicals and plasmid}

Fluo-4 was purchased from Invitrogen (Carlsbad, CA, USA). BBP, 2-aminoethoxydiphenyl borate (2-APB), and 6-diamidino-2-phenylindole (DAPI) were purchased from Sigma-Aldrich Co. (St. Louis, MO, USA). Pd98059 and wortmannin were obtained from CalbiochemNovabiochem (San Diego, CA, USA).

pEGFP-C1-AhR, a kind gift from Dr. Hsin-yu Lee (Department of Life Science, National Taiwan University), was cloned the AhR gene into pEGFP-C1 (Clontech).

\section{Cell culture}

Huh7 cells were cultured in Dulbecco's modified Eagle's medium (DMEM) (Life Technologies, Grand Island, NY, USA), PLC/PRF/5 and HepG2 cells were cultured in minimum essential medium (MEM) (Life Technologies, Grand Island, NY, USA) and supplemented with 10\% fetal bovine serum (Gibco, California,CA, USA), 1\% penicillin (100 U/mL), streptomycin $(10 \mu \mathrm{g} / \mathrm{mL})$, and amphotericinB $(250 \mu \mathrm{g} / \mathrm{mL})$ (Sigma-Aldrich Co, St. Louis, MO). Human umbilical vein endothelial cells (HUVEC) were grown in EGM-2 medium (Lonza, Basel, Switzerland). All cells were cultured at $37^{\circ} \mathrm{C}$ in $5 \% \mathrm{CO}_{2}$.

\section{Total internal reflection fluorescennce microscopy}

For total internal reflection fluorescennce (TIRF) microscopy studies, Huh7 cells were transfected with pEGFPC1-AhR or pEGFP-C1 as a control using LT1 transfection reagent (Mirus, Madison, WI, USA). After transfection for 24 hours, the cells were harvested and cultured on coverslips for 1 day. Cells were then treated with DMSO as a control or BBP $(1 \mu \mathrm{M})$ and analyzed by TIRF microscopy (Carl Zeiss, Oberkochen, Germany). GFP intensity was analyzed by Axio Vision Rel. 4.8 software (Carl Zeiss, Oberkochen, Germany).

\section{Calcium imaging}

Calcium imaging was performed using the same method as in a previous study [19] with some modifications. For live cell calcium imaging, Cell-R software was used for microscopy (Olympus, Japan). Huh7 cells were seeded on coverslips and cultured for 24 hours. Cells were incubated with $1 \mu \mathrm{M}$ Fluo-4, a $\mathrm{Ca}^{2+}$-specific dye, at $37^{\circ} \mathrm{C}$ for 20 minutes in Buffer Salt Saline (BSS) (2 mM $\mathrm{CaCl}_{2}, 5.5 \mathrm{mM}$ D-glucose, $130 \mathrm{mM} \mathrm{NaCl}, 5.4 \mathrm{mM} \mathrm{KCl}$, $20 \mathrm{mM}$ HEPES $\mathrm{pH}=7.4,1 \mathrm{mM} \mathrm{MgSO} 4$ ) and then washed three times before measuring the relative fluorescence intensity. Cells were pretreated with various concentrations of 2-APB for 10 minutes, and then loaded with $1 \mu \mathrm{M}$ Fluo-4 for 20 minutes. After washing, cells were maintained in calcium-free medium $(5.5 \mathrm{mM}$ D-glucose, $130 \mathrm{mM} \mathrm{NaCl}, 5.4 \mathrm{mM} \mathrm{KCl}, 20 \mathrm{mM}$ HEPES $(\mathrm{pH}=7.4)$, and $\left.3 \mathrm{mM} \mathrm{MgSO}_{4}\right)$ during the experimental periods. The cells were then stimulated by adding BBP $(1 \mu \mathrm{M})$ after 1 minute. Data were analyzed with Cell-R software. 


\section{Confocal microscopy}

Huh7 cells were transfected with pEGFP-C1-AhR using LT1 transfection reagent. After overnight transfection, the cells were harvested and cultured on coverslips for 1 day. BBP $(1 \mu \mathrm{M})$ was added to stimulate the cells before analysis by confocal microscopy. GFP intensity was analyzed by FV10-ASW 3.0 software (Olympus, Japan).

\section{Double immunogold transmission electron microscopy}

Ultrathin sections of plastic-embedded cells were pretreated with $5 \%$ sodium metaperiodate $(10 \mathrm{~min})$ by microwave fixation and processing. The grids were incubated with an aliquot of IgG antibodies against AhR or $\mathrm{G \alpha}_{\mathrm{q} / 11}$ (Santa Cruz Biotechnology, Santa Cruz, CA, USA) followed by probing with secondary antimouse IgG gold particles $(6 \mathrm{~nm})$ or anti rabbit IgG gold particles $(20 \mathrm{~nm})$, respectively. After washing, the sections were blocked by placing the grids on a drop of phosphate-buffered saline (PBS) containing 1\% ovalbumin and incubating for 15 minutes. Sections were then stained with uranyl acetate and lead citrate for characterization by transmission electron microscopy (H-700, Hitachi, Japan).

\section{Fluorescence in situ hybridization}

After treatment with BBP $(1 \mu \mathrm{M})$ or DMSO for the control group, cells were fixed by adding fixation solution (in $3.7 \%$ formaldehyde/PBS) at room temperature for 10 minutes. The cells were washed with PBS twice and then permeabilized by adding $70 \% \mathrm{EtOH}$ at $4^{\circ} \mathrm{C}$ for 1 hour. Cells were then washed in wash buffer $(5 \mathrm{~mL}$ 20x saline-sodium citrate (SSC), $5 \mathrm{~mL}$ formamide, and nuclease-free water to a final volume of $50 \mathrm{~mL}$ ) for $5 \mathrm{mi}$ nutes. Hybridization was performed by mixing $100 \mu \mathrm{L}$ of hybridization solution $(1 \mathrm{~g}$ dextran sulfate, $20 \times \mathrm{SSC}, 1 \mathrm{~mL}$ formamide for a $10 \%$ final concentration and nuclease-free water to a final volume of $10 \mathrm{~mL}$ ) with a specific $A h R$ probe (Stellaris ${ }^{\mathrm{Tm}}$ FISH Probes, Biosearch Technology, Novato, CA, USA) and incubating the mixture overnight at $37^{\circ} \mathrm{C}$. Cells were then stained with DAPI $(1 \mu \mathrm{g} / \mathrm{mL})$ for 5 minutes. After washing, a drop of mounting solution was applied. The slides were then covered with the cellattached cover glasses and sealed with nail polish. Imaging was performed by confocal microscopy.

\section{RNA isolation and RT-PCR}

Huh7 cells $\left(3 \times 10^{5}\right)$ were seeded in six-well plates, cultured for 24 hours, and then incubated overnight in serum free medium. The cells were then treated with BBP $(1 \mu \mathrm{M})$ for various times intervals. After stimulation, cells were washed twice with PBS. Total RNA was extracted with TRIzol (Invitrogen). The RNA $(2 \mu \mathrm{g})$ was applied to a Reverse Transcription System (Promega Biosciences, San Luis Obispo, CA, USA) to synthesize cDNA. The cDNA was then amplified by specific primers.
The primer pairs were as follows: AhR, forward 5'TACTCTGCCGCCCAA ACTGG-3', reverse 5'-GCTCT GCAACCTCCGATTCC-3'; $\beta$-actin, forward 5 '-CTCGC TGTCCACCTTCCA-3', reverse 5'-GCTGTCACCTT CACCGTTC- $3^{\prime}$. The PCR conditions were $95^{\circ} \mathrm{C}$ for $5 \mathrm{~min}$, and then 34 cycles of $95^{\circ} \mathrm{C}$ for $30 \mathrm{sec}, 54^{\circ} \mathrm{C}$ for $30 \mathrm{sec}$, and $72^{\circ} \mathrm{C}$ for $1 \mathrm{~min}$, and a final extension at $72^{\circ} \mathrm{C}$ for $10 \mathrm{~min}$. PCR products were separated on $2 \%$ agarose gels and visualized using ethidium bromide.

\section{siRNA and shRNA transfection}

The following siRNAs were used: scrambled siRNA sense: 5'-GAUCAUACGUGCGAUCAGA-3', antisense: 5'-UCU GAUCGCACGUAUGAUC-3' ; AhR siRNA (SASI_Hs02 00332181, Sigma). The following shRNAs were obtained from the National RNAi Core Facility at Academic Sinica: control shRNA, 5'-TACAACAGCCACAACGT CTAT-3'; AhR shRNA (1) (TRCN0000021255), AhR shRNA (2) (TRCN00000245285), NF-kB shRNA (1) (TRCN 0000006518), and NF-kB shRNA (2) (TRCN0000006520). Cells were transfected with siRNA $(10 \mathrm{nM})$ or shRNA $(2 \mu \mathrm{g})$ using LT1 transfection reagent.

\section{Immunoblot analysis}

Whole cell extracts were prepared in RIPA lysis buffer (Millipore, Temecula, CA, USA) containing $1 \times$ protease inhibitor cocktail (Thermo Scientific, Waltham, MA, USA). Protein concentrations were determined using a BCA protein assay kit (Thermo Scientific, Rockford, IL, USA). Equal amounts of protein $(50 \mu \mathrm{g}$ protein) were resolved by sodium dodecyl sulfate-polyacaryamide gel electrophoresis (SDS-PAGE), transferred onto a polyvinylidene difluoride membrane, and blocked with 5\% nonfat dry milk for 1 hour at room temperature. After blocking, the membrane was incubated overnight with primary antibodies at $4^{\circ} \mathrm{C}$ and washed three times with PBST. The horseradish peroxidase conjugated secondary antibodies (Santa Cruz Biotechnology) were incubated for 1 hour at room temperature. The blots were washed three times with PBST and then visualized with an enhanced chemiluminescence kit (Thermo Scientific, Rockford, IL, USA). The primary antibodies were as follows: AhR, $G \alpha_{q / 11}, G_{\beta}$, PIP2, IP3R, and PI3K from Santa Cruz Biotechnology (1:100); p44/42 MAPK (Erk1/2), Akt, p-Akt (ser473), NFkB, LaminA/C, Histion H3 and $\alpha$-tubulin from Cell Signaling Technology (1:1000); COX-2 from Abcam (1:1000); $\beta$-actin from Sigma (1:1000).

\section{Immunoprecipitation}

After preclearing for 30 minutes with protein $G$ agarose (Millipore), antibodies specific for $\mathrm{G \alpha}_{\mathrm{q} / 11}, \mathrm{G}_{\beta}$, or PI3K (1:100; Santa Cruz Biotechnology) or IgG ( $2 \mu \mathrm{g}$, SigmaAldrich Co, St. Louis, MO, USA) were added before overnight incubation at $4^{\circ} \mathrm{C}$, followed by precipitation 
for 2 hours with protein $G$ agarose. The beads were washed three times with RIPA lysis buffer, boiled in sample buffer, and the protein were resolved by $8 \%$ SDSPAGE before performing immunoblot analysis of the indicated proteins.

\section{Transwell migration and invasion assays}

Cell migration assays were performed in 24-well inserts $(8-\mu \mathrm{m}$ pore size; BD Biosciences, Franklin Lakes, NJ, USA) and cell invasion assays were performed in 24-well Matrigel $^{\mathrm{TM}}$ Invasion inserts $(8-\mu \mathrm{m}$ pore size; BD Biosciences, Franklin Lakes, NJ, USA). Cells $\left(1 \times 10^{4}\right)$ in serum-free DMEM were seeded in the upper chamber of the insert and DMEM containing 10\% fetal bovine serum was added to the lower chamber and followed by incubation for 1 day (for migration) or 2 days (for invasion). The medium and cells were then removed from the top chamber using cotton swabs and PBS. The cells were fixed with $4 \%$ paraformaldehyde for 30 minutes, stained with a $0.5 \%$ crystal violet solution for 2 hours, and counted under a microscopy.

\section{Measurement of vascular endothelial growth factor}

Huh7 cells were grown in 12-well plates and treated with BBP for 1 day. After treatment, the cells were incubated in fresh medium for 1 day. The media were then collected and centrifuged at 1,000 rpm for 5 minutes to remove cell debris. Vascular endothelial growth factor (VEGF) levels in the conditioned medium were measured with an enzymed-linked immunosorbent assay (ELISA) kit (R\&D System, Minneapolis, MN, USA).

\section{Angiogenesis tube formation assay}

HUVEC $\left(2 \times 10^{4}\right.$ cells $\left./ \mathrm{mL}\right)$ were seeded in a 48 -well plate pre-coated with Matrigel (BD Biosciences, San Jose, CA, USA). After Huh7 cell-conditioned medium was added to a final volume of $20 \%$, the cells were cultured for 16 hours, stained with calcium-AM (Invitrogen), and visualized under a fluorescence microscope (Olympus). Total tube lengths were measured by MetaMorph software (Leica)

\section{Animals}

Male 6-week-old nude mice (BALB/cA-nu nu/nu) were purchased from the National Science Council Animal Center (Taiwan). All animal experiments were performed according to a protocol approved by the Institutional Animal Care and Use Committee of Kaohsiung Medical University Hospital (IACUC Approval No: 101060).

\section{In vivo tumor xenograft experiments}

Huh7 cells were stably transfected with infrared fluorescent protein [20]. Briefly, $293 \mathrm{~T}$ cells were transfected with pCMV- $\triangle$ R8.91, pMD.G, and pLKO AS3-reporter gene using LT1 transfection reagent for 3 days, and the supernatant (lentivirus-containing medium) was collected the next day. Huh7 cells $\left(2 \times 10^{5}\right)$ were seeded into six-well plates and incubated for 1 day. The lentiviruscontaining medium $(200 \mu \mathrm{L})$ was mixed with $800 \mu \mathrm{L}$ of DMEM containing $8 \mu \mathrm{g} / \mathrm{mL}$ polybrene and added to each well, and the cells were incubated for 1 day. A stable clone was selected by puromycin treatment ( $2 \mu \mathrm{g} / \mathrm{mL}$ ) for 14 days. The cells were incubated with $25 \mu \mathrm{M}$ biliverdin overnight and then purified Huh7-IFP cells by flow cytometry. The hepatocellular carcinoma model of direct intrahepatic injection was performed according to a previous study [21] with some modifications. After a small incision was made in nude mice to access the liver, Huh7-IFP cells $\left(1 \times 10^{6}\right)$ suspended in PBS were slowly injected into the upper left lobe of the liver using a 28-gauge needle. A transparent bleb of cells was formed through the liver capsule after injection. To prevent bleeding, a small piece of sterile gauze was placed, and light pressure was applied on the injection site. After implantation, the mice were placed on a heating pad or below a heating lamp until fully active. The mice were randomly divided into two groups (vehicle or BBP treatment), 18 mice of each. After 3 days, BBP $(500 \mathrm{mg} / \mathrm{kg}$ ) was administered by intraperitoneal (i.p.) injection every 2 days. Previous studies have reported that administration of BBP by i.p. at a dose of $800 \mathrm{mg} / \mathrm{kg}$ for 24 weeks results in no significant toxic effects $[11,22]$, which is a higher dose than that used in this study. Tumor growth was detected by injecting biliverdin (250 nM) into the tail vein 30 minutes before imaging. After 1 month, the mice were sacrificed and the organs (liver, lungs, kidneys, and spleen) were removed and viewed with an Ultra Sensitive Molecular Imaging System (Berthold Technology). The numbers of the organs (lung, kidneys, spleen) that expressed fluorescence, considered as metastasis positive organs were determined.

\section{Immunohistochemistry}

Liver tissues were fixed with $4 \%$ paraformaldehyde, embedded in paraffin, and cut into 4- $\mu \mathrm{m}$ thick sections. The sections were deparaffinized in xylene and rehydrated with a graded series of ethanol/water solutions $(100 \%$ and $95 \%$ ethanol) and then water washes. The sections were treated with $10 \mathrm{mM}$ citrate buffer at $95^{\circ} \mathrm{C}$ to retrieve antigens and blocked with $5 \%$ bovine serum albumin. Primary antibodies against PI3K (1:100; Santa Cruz Biotechnology) and NF-кB (1:200; Cell Signaling) were applied to the sections at $4{ }^{\circ} \mathrm{C}$ overnight, and then the sections were incubated with secondary antibodies and 3,3'-diaminobenzidine. Intensities of PI3K and NF- $\mathrm{kB}$ staining were analyzed by Tissue Quest software (Tissue Genomics) 


\section{In vivo Matrigel ${ }^{\mathrm{TM}}$-plug angiogenesis assay}

Huh7 cells $\left(3 \times 10^{6}\right)$ were suspended in $150 \mu \mathrm{L}$ PBS, mixed with $50 \mu \mathrm{L}$ Matrigel (BD Biosciences), and injected into the flanks of nude mice. BBP $(1 \mu \mathrm{M})$ was added to the cell suspensions of the treatment groups. After 21 days, the Matrigel plugs were removed. Hemoglobin levels were determined by Drabkin reagent (Sigma), and protein concentrations were normalized to measure blood vessel formation.

\section{Statistical analysis}

Statistical significance was established using the Student's $t$-test. A $p$-value of $<0.05$ was considered statistically significant.

\section{Results}

\section{BBP induced AhR expression}

The effect of BBP on $A h R$ mRNA expression was examined by RT-PCR. BBP transiently increased $A h R$ mRNA expression until it reached its highest level at 15 minutes after treatment (Figure 1A). Next, we examined the RNA level using a specific $A h R$ mRNA probe. As a result, $A h R$ mRNA expression was increased at 15 minutes after BBP teratment, which was comparable with the RT-PCR results (Figure 1B). Immunoblot analysis of the effect of BBP on AhR expression showed that BBP stimulated AhR expression in a time-dependent manner (Figure 1C).

\section{BBP activates AhR at the cell membrane, which interacts} with $\mathrm{G}$ proteins

To investigate whether AhR can be activated at the cell membrane by BBP, Huh7 cells were transfected with pEGFP-C1 as a plasmid control or pEGFP-C1-AhR treated with DMSO as a viechle control or BBP, and then analyzed by TIRF microscopy. AhR-GFP expression peaked at 2 minutes after BBP treatment (Figure 2A). Analysis of AhR movement in Huh7 cells showed that AhR expression near the membrane increased in a time-dependent manner. The experiment was performed by confocal microscopy and analyzed by FlowView 3.0 (Olympus, Japan) (Figure 2B). Stimulation of both $\mathrm{G \alpha}_{\mathrm{q} / 11}$ and $\mathrm{G}_{\beta}$ expression by $\mathrm{BBP}$ was analyzed by immunoblotting (Figure 2C). Double immunogold transmission electron microscopy and immunoprecipitation (Figure 2D, 2E) further showed an interaction between $A h R$ and $G$ proteins. The action of AhR was notably nongenomic. To investigate whether the G-protein signaling induced by BBP was AhR dependent, we knocked down AhR using an AhR shRNA. The results showed that BBP-induced $G \alpha_{q / 11}$ and $G_{\beta}$ expression was suppressed by transfection of the AhR shRNA (Figure 2F).

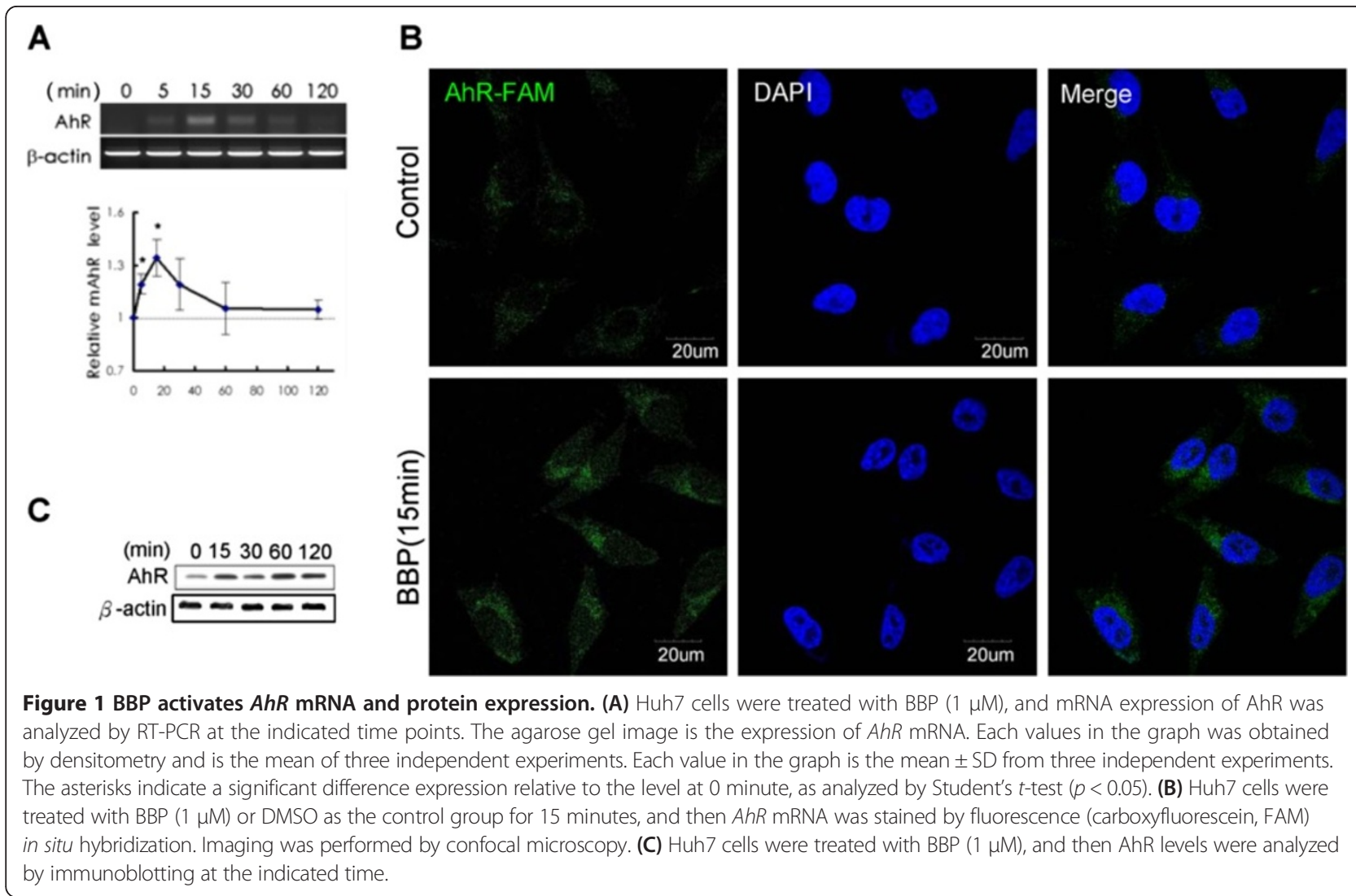




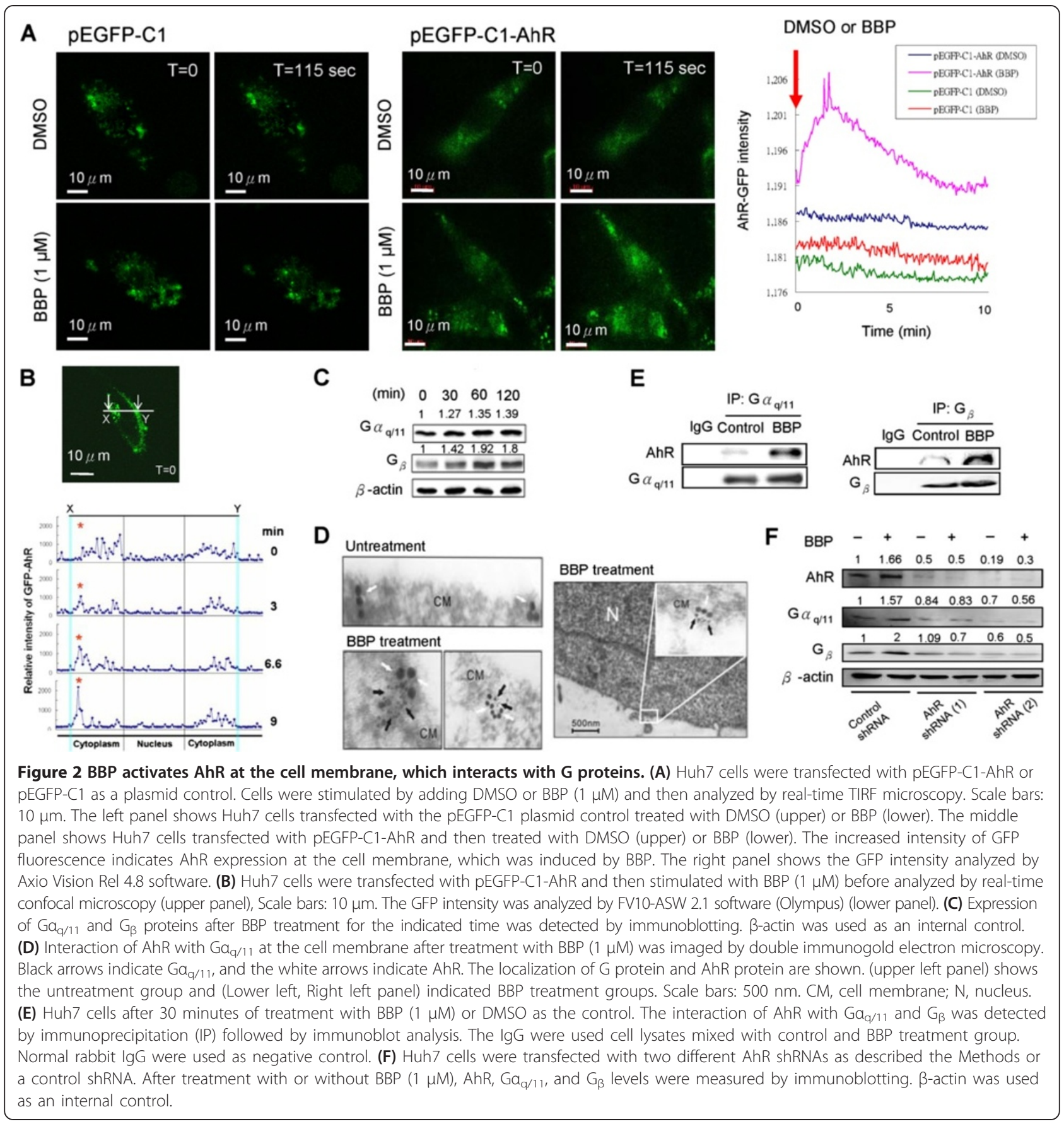

Initial activation of COX-2 by $\mathrm{AhR} / \mathrm{Ga}_{\mathrm{q} / 11}$ signaling

Downstream signaling triggered by $G \alpha_{\mathrm{q} / 11}$ was measured by immunoblot analysis of $G \alpha_{\mathrm{q} / 11}$, PIP2 and IP3R levels. A decrease in PIP2 and an increase in IP3R indicated cleavage of PIP2 to IP3, followed by activation of IP3R (Figure 3A) [23]. The calcium response to BBP was then analyzed with a live-cell calcium imaging system that showed a sharp signal immediately after BBP addition (Figure 3B). To determine whether the calcium was derived from external or internal stores, calcium-free medium was used in a second round of experiments. As a result, calcium release was quickly stimulated by addition of BBP, presumably from internal stores (Figure $3 \mathrm{C}$ ). The results were then confirmed using 2-APB, an IP3R inhibitor. 2-APB inhibited the internal release of calcium in a dose-dependent manner (Figure 3D). Expression of COX-2 was activated by BBP and inhibited by 2 -APB (Figure 3E, 3F). These results suggest that BBP promotes COX-2 expression via $\mathrm{AhR} / \mathrm{G \alpha} \alpha_{\mathrm{q} / 11} / \mathrm{calcium}$ signaling. 


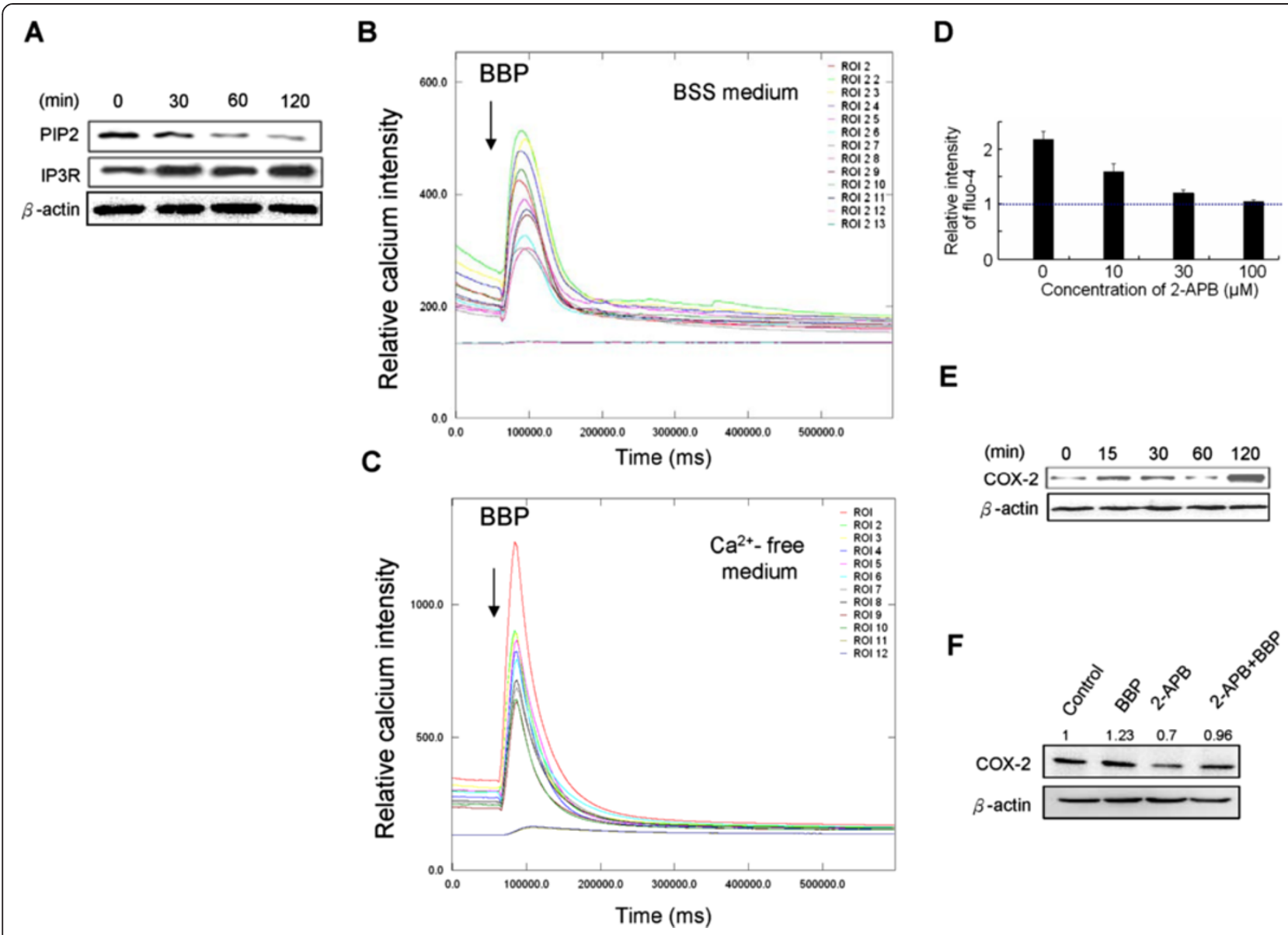

Figure 3 AhR triggers $\mathrm{Ga}_{\mathrm{q} / 11} /$ calcium/COX-2 signaling. (A) BBP induced a reduction in the level of PIP2 and activation of IP3R via Ga Huh7 cells treated with BBP $(1 \mu \mathrm{M})$, protein levels were analyzed by immunoblotting at the indicated time points. (B) Real-time imaging of calcium was performed by Cell-R microscopy. The experiment was performed in BSS medium. (C) Elevated intracellular calcium was induced by BBP treatment. The experiment was performed with a calcium free medium. The arrows indicate the time points of BBP $(1 \mu M)$ addition $(1$ minute after the experiment started). The fluorescence intensity (Y-axis) indicates the relative calcium levels. (D) Huh7 cells in calcium-free medium were pretreated with various concentrations of 2-APB for 30 minutes before stimulation with BBP $(1 \mu \mathrm{M})$. Internal calcium release was inhibited by 2-APB in a dose-dependent manner. The relative intensity of fluo-4 indicates the calcium levels: peak/baseline ratio of fluorescence intensity. Calcium-free medium was used for each experimental interval. Each value in the graph is the mean \pm SD of six replicate using at least ten cells. (E) COX-2 expression after BBP treatment was measured by immunoblotting. Huh7 cells were treated with BBP $(1 \mu \mathrm{M})$ for the indicated times before harvesting the cells. $\beta$-actin was used as an internal control. (F) Huh7 cells were pretreated with 2-APB $(20 \mu \mathrm{M})$ for 2 hours and followed by treated with BBP $(1 \mu \mathrm{M})$. Control groups were treated with DMSO. COX-2 levels were suppressed by 2-APB pretreatment.

\section{Effect of BBP on cell migration and invasion through AhR/G ${ }_{\beta} / P I 3 K / A k t / N F-K B$ signaling}

$\mathrm{G}_{\beta}$ protein activates PI3K by direct binding [24]. Immunoprecipitation was performed to examine the effect of BBP treatment on interactions between $G_{\beta}$ protein and PI3K (Figure $4 \mathrm{~A}$ ). The binding of $\mathrm{G}_{\beta}$ protein to PI3K was increased after BBP treatment. To further study the downstream pathway triggered by $\mathrm{G}_{\beta}$ activation, we analyzed PI3K enhancement and Akt phosphorylation by immunoblotting. PI3K and Akt phosphorylation level were increased after BBP treatment (Figure 4B). We also found translocation of NF- $\mathrm{kB}$ into the nucleus (Figure $4 \mathrm{C}$ ). Treatment with a PI3K inhibitor (wortmannin) reduced Akt phosphorylation (Figure 4D) and inhibited NF-kB translocation into the nucleus (Figure 4E). To further confirm whether PI3K/Akt/ NF- $\mathrm{kB}$ activation is specifically stimulated by BBP via AhR, we transfected Huh7 cells with two different AhR shRNAs. The increase of PI3K and p-Akt (Figure 4F), and translocation of NF- $\mathrm{BB}$ into the nucleus (Figure 4G) induced by BBP were inhibited by transfection of the shRNAs. PI3K/Akt/NF-kB enhances cell migration and invasion [25]. Thus, we further investigated the mechanisms of cell migration and invasion which are induced by BBP. Huh7 cells were transfected with two different AhR shRNAs, NF-kB shRNA, or control shRNA for 48 hours, followed by preparation of cell lysates. The protein levels of AhR and NF-kB markedly decreased after transfection with $A h R$ and 


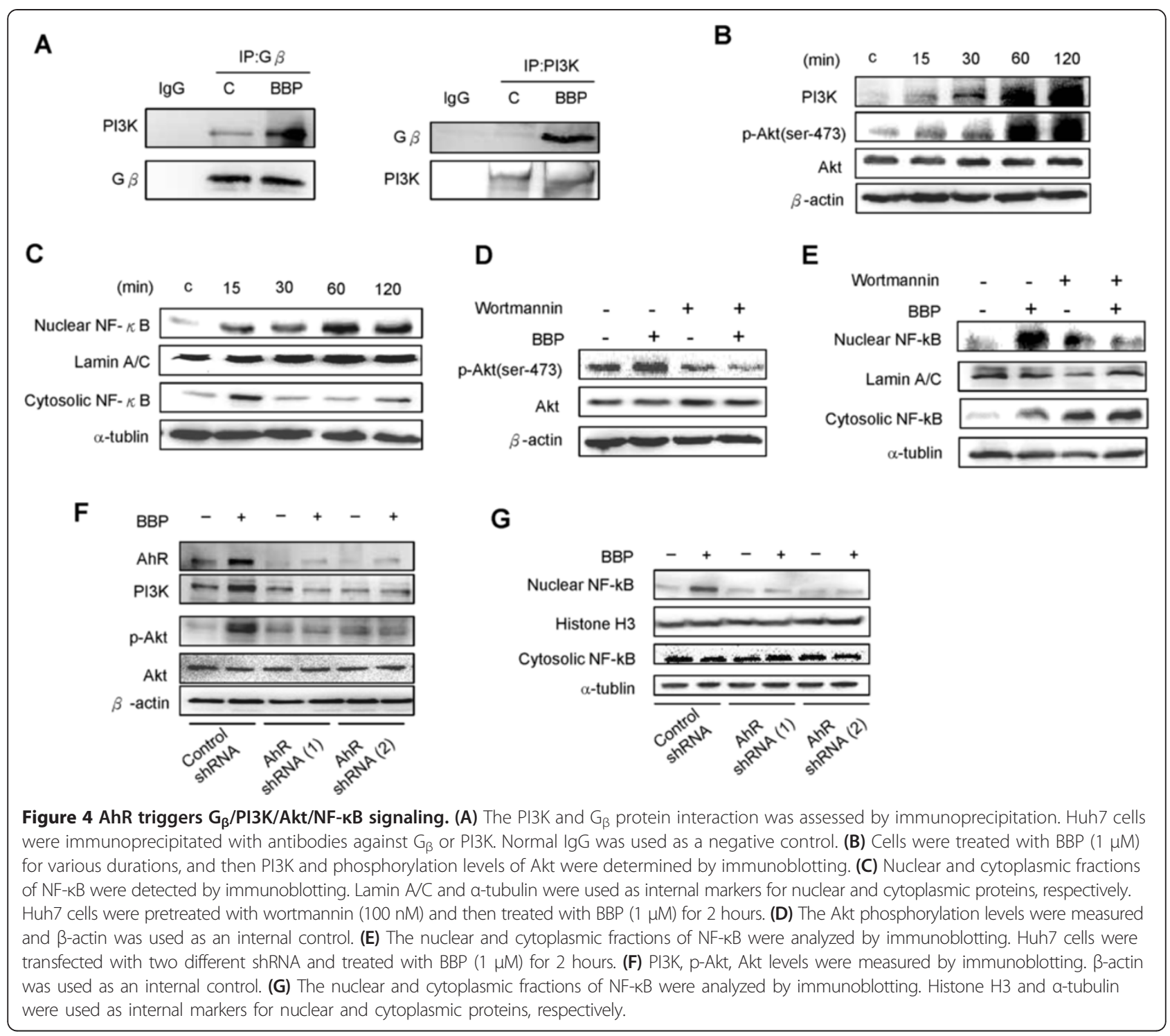

NF- $\mathrm{kB}$ shRNAs compared with those after transfection with control shRNA (Figure 5A). To further study the effects of BBP on Huh7 cells migration and invasion, transwell migration and invasion assays were performed. AhR and NF- $\mathrm{kB}$ shRNAs inhibited cell migration and invasion induced by BBP (Figure 5B). These results suggest that $\mathrm{BBP}$ promotes cell migration and invasion by activation of $A h R / G_{\beta} / P I 3 K / A k t / N F-k B$ signaling.

\section{BBP promotes in vivo metastasis}

The mouse intrahepatic injection model was established to examine tumor metastasis [26]. Huh7-IFP cells $\left(1 \times 10^{6}\right)$ were suspended in $30 \mu \mathrm{L}$ PBS and injected into the mouse liver (At 3 days after of implantation, $500 \mathrm{mg} / \mathrm{kg}$ BBP was administered by i.p. injection every 2 days. Weekly imaging of the mice confirmed that the tumor sizes increased over time (Figure 5C). The mice were sacrificed after 1 month to compare tumor metastasis between control and BBP treatment groups. The metastasis rates in the lungs, kidneys, and spleen were higher in the BBP treatment group than those in the control group (Figure 5D), suggesting that $\mathrm{BBP}$ promotes metastasis. Immunohistochemistry showed that liver PI3K and NF- $\mathrm{KB}$ levels were significantly higher in the treatment group than those in the control group (Figure 5E).

\section{BBP promotes angiogenesis in vitro and in vivo}

To examine the effect of BBP on angiogenesis, the conditioned medium of Huh7 cells that had been treated with BBP was examined for its ability to induce the formation of capillary-like structures by HUVEC (Figure 6A). The levels of VEGF, which promotes angiogenesis [27], were also measured in the conditioned medium (Figure 6A). To explore the associated mechanisms, Huh7 cells were 


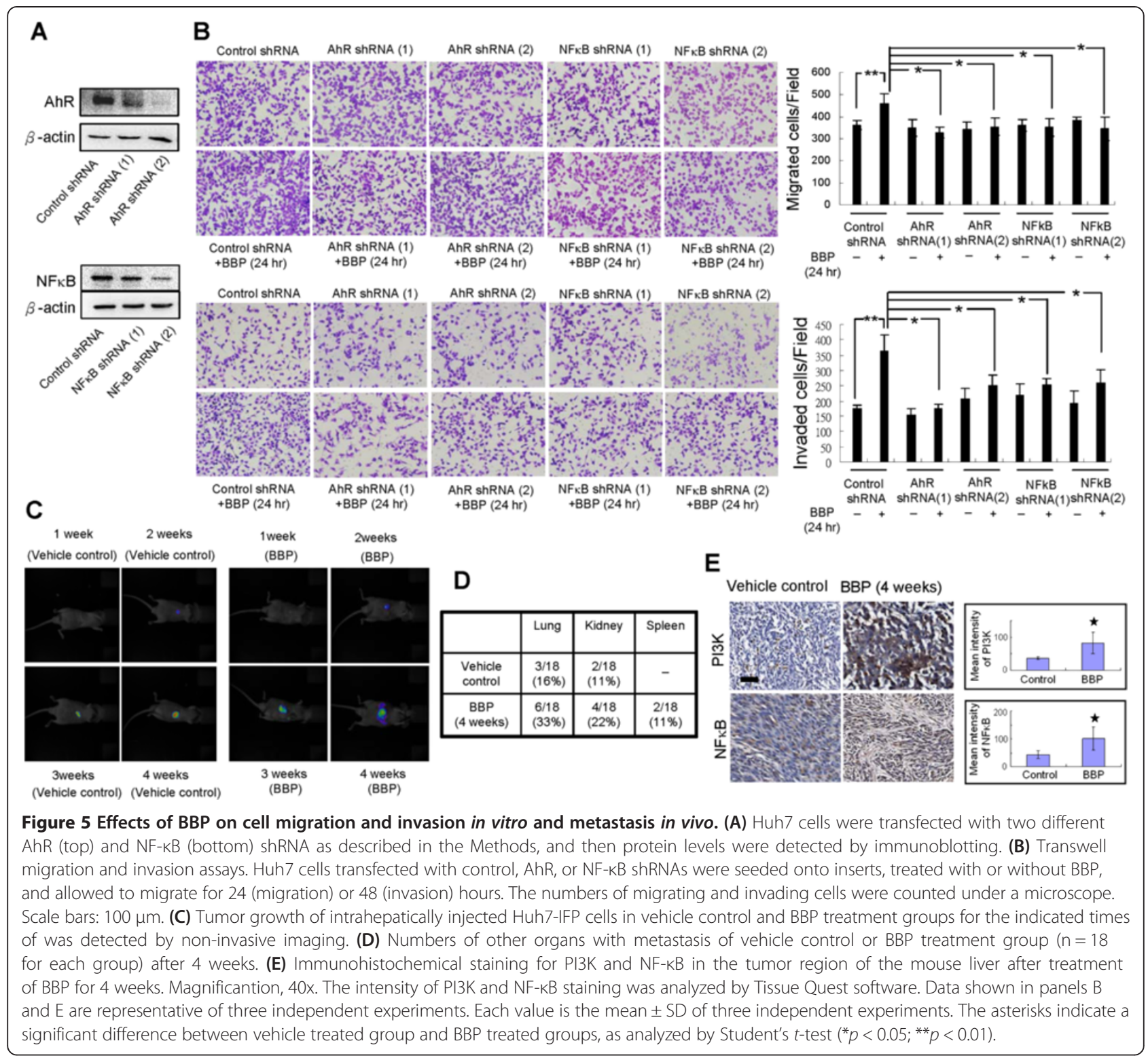

treated with the ERK inhibitor Pd98059 (Figure 6A) or transfected with AhR siRNA (Figure 6B) before collection of the medium. Analyses of the media showed that both Pd98059 and AhR siRNA inhibited tube formation of HUVEC and reduced VEGF induction after BBP treatment. Moreover, we evaluated the phosphorylation levels of ERK (Figure 6C). To further confirm whether activation of ERK was AhR dependent, we trasfected Huh7 cells with two different AhR shRNAs and the results showed inhibition of the phosphorylation levels of ERK induced by BBP (Figure 6D). The angiogenic effects of BBP were then assessed in an in vivo Matrigel plug angiogenesis assay model. Briefly, Huh7 cells were mixed with Matrigel and injected into the flanks of nude mice. After 3 weeks, the mice were sacrificed, and hemoglobin levels in the plug were measured. Hemoglobin levels in the Matrigel plug treated with BBP were significantly higher than those in the control group (Figure 6E).

\section{Discussion}

In this study, we provide evidence that phthalate promotes hepatocellular carcinoma progression through a nongenomic AhR pathway. Rodent studies of the carcinogenesis of phthalate have yielded substantial data [5]. Some human epidemiological studies have also shown a cancer risk associated with phthalate exposure, including respiratory cancer [28], pancreatic cancer [29], and breast cancer [30]. However, the mechanisms of carcinogenesis have been rarely explored for phthalate. To further investigate such mechanisms, we treated hepatocellular 


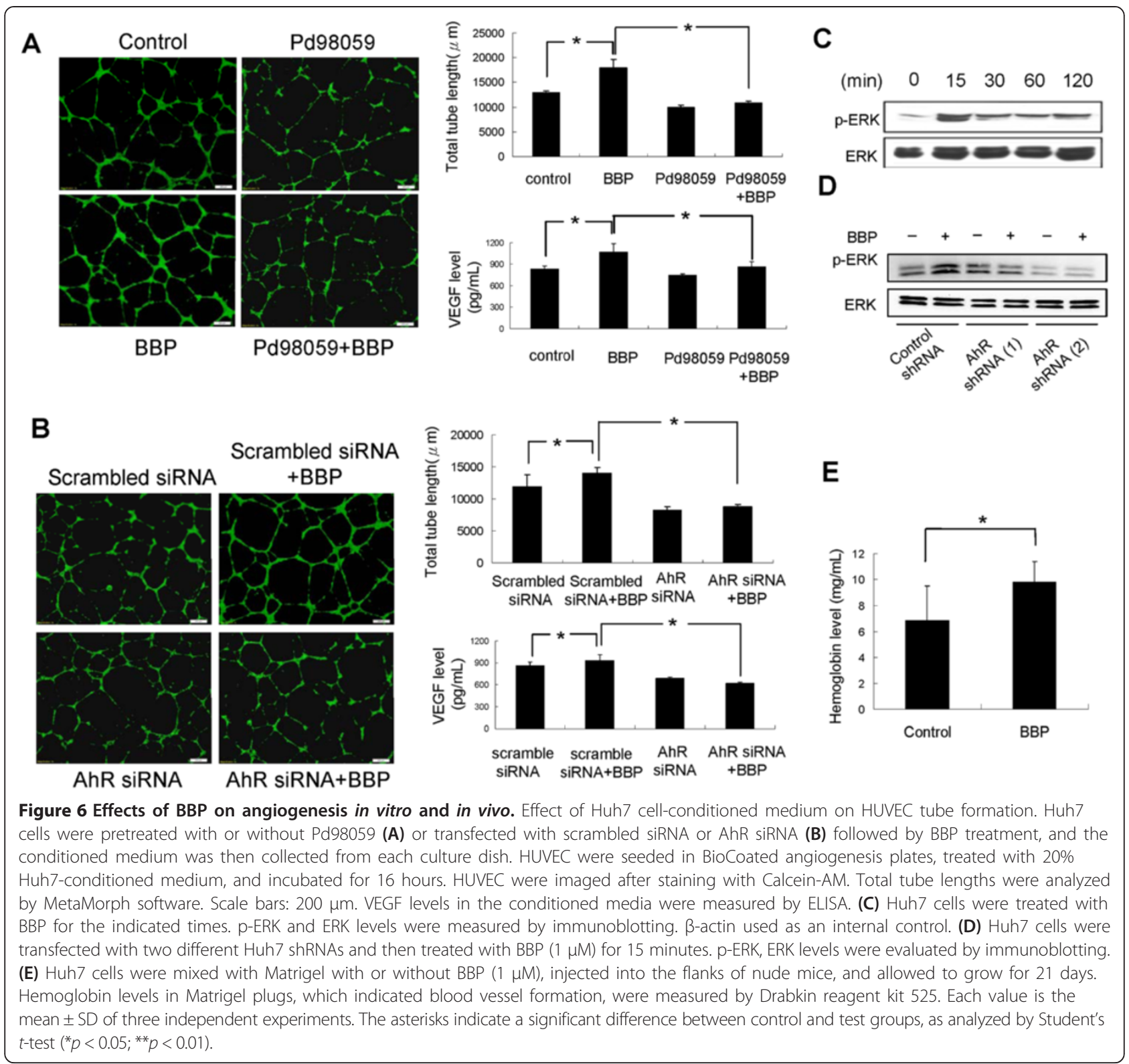

carcinoma cell lines, Huh7, HepG2 and PLC cells with BBP $(1 \mu \mathrm{M})$. All cell lines showed the activation of AhR after treatment (Additional file 1: Figure S1). We then tested the functions of cells treated with BBP including migration, invasion and angiogenesis. We found that BBP induced migration of Huh7 and PLC cell lines. In addition, BBP induced invasion and angiogenesis of Huh7 cells (Additional file 2: Figure S2). These results may be due to the higher constitutional level of AhR in Huh7 than in that in PLC cells (Additional file 2: Figure S2D). HepG2 cells are not appropriate for further animal studies for nontumorigenic properties in immunosuppressed mice [31]. Therefore, we further investigated the mechanism induced by BBP in Huh7 cells. We used Huh7 cells in the in vivo study, and clarified the effect of BBP induced metastasis and angiogenesis in vivo.

Our current study showed that BBP treatment induces a nongenomic function through $\mathrm{AhR}$ and further clarified that AhR translocates to the membrane and subsequently activates G-protein signaling. Our investigation is consistent with a previous report in the nongenomic AhR mechanism induced by TCDD, showing that TCDD rapidly increases calcium concentrations and induces COX-2 expression in U937 macrophages, mouse MMDD1 macula densa cells, and MCF10 cells [14,17]. We believe that the nongenomic action explains why cells elict fast inflammatory responses to the environmental pollutant TCDD and the endocrine disrupting agent, phthalate. After 
BBP treatment, the $A h R$ mRNA levels were unregulated. Certain molecular such as NF- $\mathrm{kB}$, interleukin (IL)-27 and IL-6 were investigated that can regulate AhR expression [32-34]. However, the mechanism of BBP induced AhR mRNA upregulation has remained unclear. Subsequently the nongenomic action triggers the cell signal pathways and affects the cell function. A previous study showed that by interacting with AhR-interacting protein, $G_{\alpha 13}$ destabilized AhR via the ubiquitin-proteasome pathway [18]. Polycyclic aromatic hydrocarbons (PAH), which is the AhR ligand, induceds expression of AhR target genes through directed bind to $G$ protein coupled receptor and activates $\mathrm{G}$ protein/ cAMP/ 1,4,5-trisphosphate (IP3) pathway, which results in calcium induction [35]. The current study further confirmed that AhR positively regulates $G$ proteins, including $G \alpha_{\mathrm{q} / 11}$ and $G_{\beta}$ through nongenomic mechnissams. To our knowledge, the present study is the first investigation to elicit that phthalate activates $A h R$ through a non-genomic mechanism that involving $G$ protein signaling. Importantly, we provide evidence that the tumor progression, including migration, invasion and angiogenesis were regulated by this phthalate-induced signaling pathways.

Immortalized fibroblasts from $\mathrm{Ahr}^{-1-}$ mice demonstrate a lower tumorigenic potential because of diminished cell motility and responses to angiogenic factors [36]. Overexpression of AhR promotes the development of malignant cellular phenotypes and also increases their cell proliferation rate, motility, migration, and confers the ability to invade Matrigel in immortalized normal human mammary epithelial cells [37]. Activation of AhR is functionally connected to a signaling cascade that dramatically alters plasticity and increases motility in MCF-7 cells [38].

Angiogenesis contributes to tumor metastasis [39]. It has been reported AhR regulates both in vitro and in vivo angiogenesis. $\mathrm{AhR}^{-/-}$endothelial cells fail to form tube-like structures, and impaired angiogenesis limits tumor xenograft growth in AhR null mice [40]. The current study showed that BBP promoted angiogenesis through nongenomic AhR mechanisms, and VEGF expression was increased by ERK $1 / 2$ phosphorylation. This finding is consistent with an earlier study showing that an ER-dependent mechanism involving activation of MEK, p38 kinase, and PI3K pathways by xenoestrogens up-regulates VEGF expression in breast cancer cells [41]. However, our current study is the first to show that BBP increases both in vitro and in vivo angiogenesis of liver cancer.

Previous reports have revealed that phthalates promote cancer cell migration, invasion and epithelial-mesenchymal transition, which may explain the cancer progression observed in both ER-dependent and AhR-dependent pathways [10,42-44]. Several reports have shown that
AhR regulates cell migration, invasion and plasticity, all of which contribute to tumor progression [10,36,45-47]. Our study showed that BBP promoted cell migration and invasion through the $A h R / G_{\beta} / P I 3 K / A k t / N F-\kappa B$ pathway in hepatocellular carcinoma cells. These indicate phthalate stimulates various cell signaling pathways of cancer cell migration and invasion. Our data showed metastasis can be promoted by phthatlate in vitro and in an animal model in vivo. This is a phenomenon need to be addressed as metastasis is the key for the prognosis of cancer treatment.

Overexpression of COX-2 occurs in many pre-malignant, malignant, and metastatic cancers, including hepatocellular carcinoma. COX-2 regulates carcinogenesis by regulating angiogenesis [48], suppressing the immune response, and by inhibiting apoptosis, and tumor cell invasion, and metastasis [49]. Our data suggest that BBP may contribute to angiogenesis, tumor cell invasion and metastasis by increasing COX-2 expression.

\section{Conclusions}

Taking these results together, we propose a signaling pathway for BBP stimulated hepatocellular carcinoma progression (Figure 7). BBP induces membrane translocation of $\mathrm{AhR}$ and the initial activation of COX-2 by $A h R / G \alpha_{q / 11}$ signaling. In addition, BBP promotes angiogenesis via the AhR/ERK/VEGF pathway and cell migration and invasion through $\mathrm{AhR} / \mathrm{G}_{\beta} / \mathrm{PI} 3 \mathrm{~K} / \mathrm{Akt} / \mathrm{NF}-\mathrm{kB}$ signaling.

In conclusion, we revealed a nongenomic AhR mechanism that may account for the modulated progression of liver cancer after phthalate exposure. Our results imply that BBP has a promoting impact on hepatocellular carcinoma, and that phthalate should be avoided in theses patients.

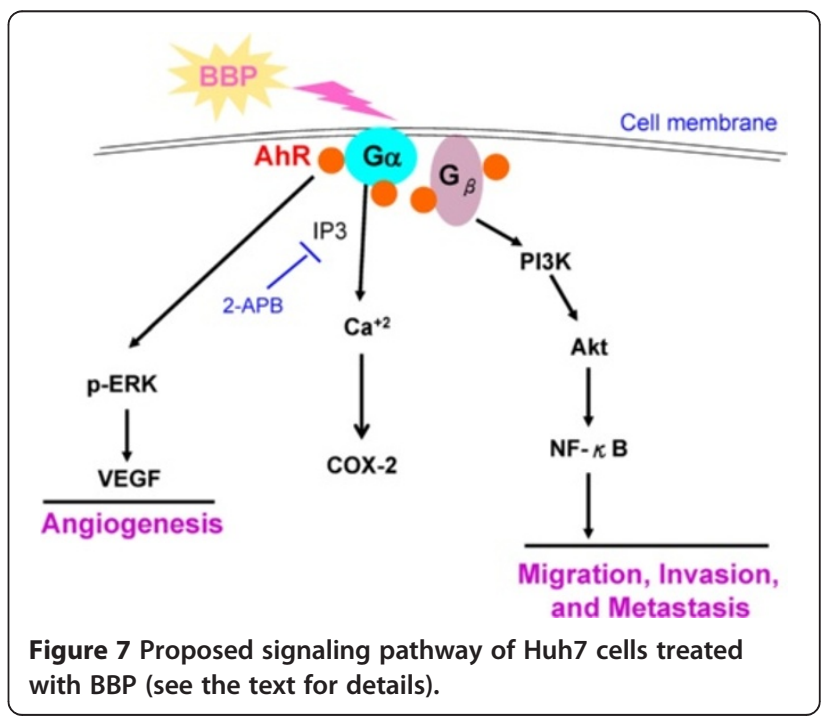




\section{Additional files}

Additional file 1: Figure S1. Effects of BBP on AhR expression of hepatocellular carcinoma cell lines. Huh7, HepG2, and PLC cells were treated with BBP $(1 \mu \mathrm{M})$ for 24 hours and AhR protein levels were then analyzed by immunoblotting. $\beta$-actin was used as an internal control.

Additional file 2: Figure S2. Effects of BBP on angiogenesis, migration and invasion. (A) Effect of conditioned media from Huh7 and PLC cells on HUVEC tube formation. After Huh7 and PLC cells were treated with BBP $(1 \mu \mathrm{M})$ for 1 day, the culture medium was changed to the fresh medium and the cells were cultured for 1 day. Conditioned medium was collected from each culture dish. HUVEC were treated with 20\% conditioned medium and incubated for 16 hours. HUVEC were imaged after staining with Calcein-AM (top). Total tube lengths were determined by MetaMorph software (bottom). Scale bar: $200 \mu \mathrm{m}$. The asterisks indicates a significant difference between control and test groups, as analyzed by Student's t-test $(* p<0.05)$. (B) Transwell migration assay. (C) Transwell invasion assay. Huh7 and PLC cells were seeded on inserts and treated with BBP $(1 \mu \mathrm{M})$. Scale bars: $100 \mu \mathrm{m}$. (D) Huh7 and PLC cells were harvested to prepare whole cell lysates for AhR protein levels were measured by immunoblotting, $\beta$-actin was used as an internal control.

\section{Abbreviations}

(BBP): Benzyl butyl phthalaye; (AhR): Aryl hydrocarbon receptor (DEHP): Bis(2-ethylhexyl) phthalate; (TCDD): 2,3,7,8-tetrachlorodibenzo-pdioxin; (2-APB): 2-aminoethoxydiphenyl borate; (DAPI): 6-diamidino-2phenylindole; (PBS): Phosphate-buffered saline; (SSC): Saline-sodium citrate; (i.p): Intraperitoneal; (DRE): Dioxin response element.

\section{Competing interests}

The authors declare that they have no competing interests.

\section{Authors' contributions}

CFT conducted the experiments and wrote the manuscript. THH and $\mathrm{CYH}$ analyzed the data. JNL, EMT and PLK participated in the study design. YCW conducted the animal experiments. FJ consulted on the double immunogold transmission electron microscopy experiment. KKK and HLW helped to draft the manuscript. All authors approved the final version of the manuscript.

\section{Acknowledgements}

We thank the Center for Resources, Research, and Development of Kaohsiung Medical University for support with instrumentation and the Laboratory Anima Center of Kaohsiung Medical University for assistance with animal experiments.

\section{Funding}

This work was supported by the National Science Council, Taiwan [grant number 102-2628-B-037-011-MY3 and 102-2632-B-037-001-MY3]. Kaohsiung Medical University (Hospital) Research Fund [grant numbers KMUH102-2R22, KMUH101-1R27, KMUH100-0R24]. National Sun Yat-Sen University-KMU Joint Research Project (\#NSYSUKMU 102-P029).

\section{Author details}

${ }^{1}$ Graduate Institute of Medicine, College of Medicine, Kaohsiung Medical University, Kaohsiung City 807, Taiwan. ${ }^{2}$ Department of Obstetrics and Gynecology Kaohsiung Medical University Hospital, Kaohsiung Medical University, No. 100, Zihyou 1st Rd., Sanmin District, Kaohsiung City 807, Taiwan. ${ }^{3}$ Department of Dermatology, Chi-Mei Medical Center, 901 Chung Hwa Road, Yung Kang City, Tainan 701, Taiwan. ${ }^{4}$ Division of Hepatobiliary Pancreatic Surgery, Department of Surgery, Kaohsiung Medical University Hospital, Kaohsiung, Taiwan. ${ }^{5}$ Department of Biochemistry and Molecular Biology, National Cheng Kung University, Tainan, Taiwan. ${ }^{6}$ Cardiovascular Research Center, College of Medicine, National, Cheng Kung University, Tainan, Taiwan. ${ }^{7}$ Center for Bioscience and Biotechnology, National Cheng Kung University, Tainan, Taiwan. ${ }^{8}$ Center for Resources, Research and Development, Kaohsiung Medical University, Kaohsiung City 807, Taiwan. ${ }^{9}$ Institute of Clinical Medicine, College of Medicine, Kaohsiung Medical University, No. 100, Zihyou 1st Rd., Sanmin District, Kaohsiung, Taiwan.

Received: 28 October 2013 Accepted: 18 July 2014

Published: 1 August 2014

\section{References}

1. Ferlay J, Shin HR, Bray F, Forman D, Mathers C, Parkin DM: Estimates of worldwide burden of cancer in 2008: GLOBOCAN. Int J Cancer 2010, 127(12):2893-2917

2. Chuang SC, La Vecchia C, Boffetta P: Liver cancer: descriptive epidemiology and risk factors other than HBV and HCV infection. Cancer Lett 2009, 286(1):9-14.

3. Seo KW, Kim KB, Kim YJ, Choi JY, Lee KT, Choi KS: Comparison of oxidative stress and changes of xenobiotic metabolizing enzymes induced by phthalates in rats. Food Chem Toxicol 2004, 42(1):107-114

4. Ward JM, Diwan BA, Ohshima M, Hu H, Schuller HM, Rice JM: Tumorinitiating and promoting activities of di(2-ethylhexyl) phthalate in vivo and in vitro. Environ Health Perspect 1986, 65:279-291.

5. Voss C, Zerban H, Bannasch P, Berger MR: Lifelong exposure to di-(2-ethylhexyl)-phthalate induces tumors in liver and testes of Sprague-Dawley rats. Toxicology 2005, 206(3):359-371.

6. Choi S, Park SY, Kwak D, Phark S, Lee M, Lim JY, Jung WW, Sul D: Proteomic analysis of proteins secreted by HepG2 cells treated with butyl benzyl phthalate. J Toxicol Environ Health A 2010, 73(21-22):1570-1585.

7. Krüger $T$, Long $M$, Bonefeld-Jørgensen EC: Plastic components affect the activation of the aryl hydrocarbon and the androgen receptor. Toxicology 2008, 246(2-3):112-123.

8. Mankidy R, Wiseman S, Ma H, Giesy JP: Biological impact of phthalates. Toxicol Lett 2013, 217(1):50-58.

9. Kuo CH, Hsieh CC, Kuo HF, Huang MY, Yang SN, Chen LC, Huang SK, Hung CH: Phthalates suppress type I interferon in human plasmacytoid dendritic cells via epigenetic regulation. Allergy 2013, 68:870-879.

10. Chen HS, Chiang PH, Wang YC, Kao MC, Shieh TH, Tsai CF, Tsai EM: Benzyl butyl phthalate induces necrosis by AhR mediation of CYP1B1 expression in human granulosa cells. Reprod Toxicol 2011, 33(1):67-75.

11. Hsieh TH, Tsai CF, Hsu CY, Kuo PL, Lee JN, Chai CY, Wang SC, Tsai EM: Phthalates induce proliferation and invasiveness of estrogen receptornegative breast cancer through the AhR/HDAC6/c-Myc signaling pathway. FASEB J 2012, 26(2):778-787.

12. Guyot E, Coumoul X, Chassé JF, Khallouki F, Savouret JF, Poirot M, Barouki R: Identification of a new stilbene-derived inducer of paraoxonase 1 and ligand of the Aryl hydrocarbon Receptor. Biochem Pharmacol 2012, 83(5):627-632

13. Matsumura F: The significance of the nongenomic pathway in mediating inflammatory signaling of the dioxin-activated Ah receptor to cause toxic effects. Biochem Pharmacol 2009, 77(4):608-626.

14. Sciullo EM, Dong B, Vogel CF, Matsumura F: Characterization of the pattern of the nongenomic signaling pathway through which TCDDinduces early inflammatory responses in U937 human macrophages. Chemosphere 2009, 74(11):1531-1537.

15. Dong B, Matsumura F: Roles of cytosolic phospholipase $A 2$ and SrC kinase in the early action of 2,3,7,8-tetrachlorodibenzo-p-dioxin through a nongenomic pathway in MCF10A cells. Mol Pharmacol 2008, 74(1):255-263.

16. Li W, Matsumura F: Significance of the nongenomic, inflammatory pathway in mediating the toxic action of TCDD to induce rapid and long-term cellular responses in 3 T3-L1 adipocytes. Biochemistry 2008, 47(52):13997-14008

17. Dong B, Nishimura N, Vogel CF, Tohyama C, Matsumura F: TCDD-induced cyclooxygenase-2 expression is mediated by the nongenomic pathway in mouse MMDD1 macula densa cells and kidneys. Biochem Pharmacol 2010, 79(3):487-497.

18. Nakata A, Urano D, Fujii-Kuriyama Y, Mizuno N, Tago K, Itoh H: G-protein signalling negatively regulates the stability of aryl hydrocarbon receptor. EMBO Rep 2009, 10(6):622-628.

19. Hsu WL1, Tsai MH, Lin MW, Chiu YC, Lu JH, Chang CH, Yu HS, Yoshioka T: Differential effects of arsenic on calcium signaling in primary keratinocytes and malignant (HSC-1) cells. Cell Calcium 2012, 52(2):161-169.

20. Shu X, Royant A, Lin MZ, Aguilera TA, Lev-Ram V, Steinbach PA, Tsien RY: Mammalian expression of infrared fluorescent proteins engineered from a bacterial phytochrome. Science 2009, 324(5928):804-807.

21. Yao X1, Hu JF, Daniels M, Yien H, Lu H, Sharan H, Zhou X, Zeng Z, Li T, Yang $Y$, Hoffman AR: A novel orthotopic tumor model to study growth factors and oncogenesis in hepatocarcinogenesis. Clin Cancer Res 2003, 9(7):2719-2726. 
22. Singletary $\mathrm{K}$, MacDonald $\mathrm{C}$, Wallig M: The plasticizer benzyl butyl phthalate (BBP) inhibits 7, 12-dimethylbenz[a]anthracene (DMBA)-induced rat mammary DNA adduct formation and tumorigenesis. Carcinogenesis 1997, 18(8):1669-1673.

23. Liu D, Liman ER: Intracellular Ca2+ and the phospholipid PIP2 regulate the taste transduction ion channel TRPM5. Proc Natl Acad Sci U S A 2003, 100(25):151601-155165.

24. Rommel C, Camps M, Ji H: PI3K delta and PI3K gamma: partners in crime in inflammation in rheumatoid arthritis and beyond? Nat Rev Immunol 2007, 7(3):1912-01

25. Yan X, Shen H, Jiang H, Hu D, Zhang C, Wang J, Wu X: External Qi of Yan Xin $\mathrm{Q}$ gong induces apoptosis and inhibits migration and invasion of estrogen-independent breast cancer cells through suppression of Akt/ NF-kB signaling. Cell Physiol Biochem 2010, 25(2-3):263-270.

26. Ge NL, Elferink $\mathrm{CJ}$ : A direct interaction between the aryl hydrocarbon receptor and retinoblastoma protein. J Biol Chem 1998, 273(35):22708-22713.

27. Zhang L, Wang JN, Tang JM, Kong X, Yang JY, Zheng F, Guo LY, Huang YZ Zhang L, Tian L, Cao SF, Tuo CH, Guo HL, Chen SY: VEGF is essential for the growth and migration of human hepatocellular carcinoma cells. Mol Biol Rep 2012, 39(5):5085-5093.

28. Hagmar L, Akesson B, Nielsen J, Andersson C, Lindén K, Attewell R, Möller T: Mortality and cancer morbidity in workers exposed to low levels of vinyl chloride monomer at a polyvinyl chloride processing plant. Am J Ind Med 1990, 17(5):553-565

29. Selenskas S, Teta MJ, Vitale JN: Pancreatic cancer among workers processing synthetic resins. Am J Ind Med 1995, 28(3):385-398.

30. López-Carrillo L, Hernández-Ramírez RU, Calafat AM, Torres-Sánchez L, Galván-Portillo M, Needham LL, Ruiz-Ramos R, Cebrián ME: Exposure to phthalates and breast cancer risk in northern Mexico. Environ Health Perspect 2010, 118(4):5394-44

31. Wang Z, Bai Z, Zhang H, Huan T, Li J, Xiumin D, Zhang J: Growth potential of human hepatocarcinoma cells in the liver of neonatal immunocompetent mice and its relation to immunological tolerance. Prog Nat Sci 2009, 19:705-712.

32. Apetoh L1, Quintana FJ, Pot C, Joller N, Xiao S, Kumar D, Burns EJ, Sherr DH, Weiner $\mathrm{HL}$, Kuchroo VK: The aryl hydrocarbon receptor interacts with c-Maf to promote the differentiation of type 1 regulatory T cells induced by IL-27. Nat Immuno/ 2010, 11(9):854-861.

33. Monticelli S, Sallusto F: Negative regulators take center stage. Nat Immunol 2012, 13(8):7197-20

34. Champion S, Sauzet C, Bremond P, Benbrahim K, Abraldes J, Seree E, Barra $Y$, Villard PH: Activation of the NF k B Pathway Enhances AhR Expression in Intestinal Caco-2 Cells. ISRN Toxicol 2013, doi:10.1155/2013/792452

35. Mayati $A$, Levoin $N$, Paris $H$, N'diaye $M$, Courtois $A$, Uriac $P$, LagadicGossmann D, Fardel O, Le Ferrec E: Induction of intracellular calcium concentration by environmental benzo(a)pyrene involves a $\beta 2$-adrenergic receptor/adenylyl cyclase/epac-1/inositol 1,4,5-trisphosphate pathway in endothelial cells. J Biol Chem 2012, 287(6):4041-4052.

36. Mulero-Navarro S, Pozo-Guisado E, Pérez-Mancera PA, Alvarez-Barrientos A, Catalina-Fernández I, Hernández-Nieto E, Sáenz-Santamaria J, Martínez N, Rojas JM, Sánchez-García I, Fernández-Salquero PM: Immortalized mouse mammary fibroblasts lacking dioxin receptor have impaired tumorigenicity in a subcutaneous mouse xenograft model. J Biol Chem 2005, 280(31):28731-28741.

37. Brooks J, Eltom SE: Malignant transformation of mammary epithelial cells by ectopic overexpression of the aryl hydrocarbon receptor. Curr Cancer Drug Targets 2011, 11(5):654-669.

38. Diry M, Tomkiewicz C, Koehle C, Coumoul X, Bock KW, Barouki R, Transy C: Activation of the dioxin/aryl hydrocarbon receptor (AhR) modulates cell plasticity through a JNK-dependent mechanism. Oncogene 2006, 25(40):5570-5574.

39. Kirsch M, Schackert G, Black PM: Metastasis and angiogenesis. Cancer Treat Res 2004, 117:285-304.

40. Roman AC, Carvajal-Gonzalez JM, Rico-Leo EM, Fernandez-Salquero PM: Dioxin receptor deficiency impairs angiogenesis by a mechanism involving VEGF-A depletion in the endothelium and transforming growth factor-beta overexpression in the stroma. J Biol Chem 2009, 284(37):251352-255148.

41. Buteau-Lozano H, Velasco G, Cristofari M, Balaguer P, Perrot-Applanat M: Xenoestrogens modulate vascular endothelial growth factor secretion in breast cancer cells through an estrogen receptor-dependent mechanism. J Endocrinol 2008, 196(2):399-412
42. Hsieh TH, Tsai CF, Hsu CY, Kuo PL, Lee JN, Chai CY, Hou MF, Chang CC, Long CY, Ko YC, Tsai EM: Phthalates stimulate the epithelial to mesenchymal transition through an HDAC6-dependent mechanism in human breast epithelial stem cells. Toxico/ Sci 2012, 128(2):3653-3676.

43. Zhu H, Zheng J, Xiao X, Zheng S, Dong K, Liu J, Wang Y: Environmental endocrine disruptors promote invasion and metastasis of SK-N-SH human neuroblastoma cells. Oncol Rep 2010, 23(1):129-139.

44. Yao PL, Lin Y, Richburg JH: Mono-(2-ethylhexyl) phthalate (MEHP) promotes invasion and migration of human testicular embryonal carcinoma cells. Biol Reprod 2012, 86(5):1601-1670.

45. Peng TL, Chen J, Mao W, Song X, Chen MH: Aryl hydrocarbon receptor pathway activation enhances gastric cancer cell invasiveness likely through a c-Jun-dependent induction of matrix metalloproteinase-9. BMC Cell Biol 2009, 16:10-27.

46. Bui LC, Tomkiewicz C, Chevallier A, Pierre S, Bats AS, Mota S, Raingeaud J, Pierre J, Diry M, Transy C, Garlatti M, Barouki R, Coumoul X: Nedd9/Hef1/ Cas- $L$ mediates the effects of environmental pollutants on cell migration and plasticity. Oncogene 2009, 28(41):3642-3651.

47. Ambolet-Camoit A, Bui LC, Pierre S, Chevallier A, Marchand A, Coumoul X, Garlatti M, Andreau K, Barouki R, Aggerbeck M: 2,3,7,8-tetrachlorodibenzop-dioxin counteracts the $\mathrm{p} 53$ response to a genotoxicant by upregulating expression of the metastasis marker agr2 in the hepatocarcinoma cell line HepG2. Toxicol Sci 2010, 115(2):501-512.

48. Zhao QT, Yue SQ, Cui Z, Wang Q, Cui X, Zhai HH, Zhang LH, Dou KF: Potential involvement of the cyclooxygenase-2 pathway in hepatocellular carcinomaassociated angiogenesis. Life Sci 2007, 80(5):484-492.

49. Akkız H, Bayram S, Bekar A, Akgöllü E, Ülger Y: Functional polymorphisms of cyclooxygenase-2 gene and risk for hepatocellular carcinoma. Mol Cell Biochem 2011, 347(1-2):201-208.

doi:10.1186/1471-2407-14-556

Cite this article as: Tsai et al:: Benzyl butyl phthalate induces migration invasion, and angiogenesis of Huh7 hepatocellular carcinoma cells through nongenomic AhR/G-protein signaling. BMC Cancer 2014 14:556.

\section{Submit your next manuscript to BioMed Central and take full advantage of:}

- Convenient online submission

- Thorough peer review

- No space constraints or color figure charges

- Immediate publication on acceptance

- Inclusion in PubMed, CAS, Scopus and Google Scholar

- Research which is freely available for redistribution 